Electronic Journal of Research

in Educational Psychology

$\cdot$ - ejrep
Electronic Journal of Research in Educational Psychology

E-ISSN: 1696-2095

jfuente@ual.es

Universidad de Almería

España

Pegalajar-Palomino, Ma del Carmen; Colmenero-Ruiz, Ma Jesús Inteligencia emocional en alumnado de Educación Secundaria en contextos multiculturales

Electronic Journal of Research in Educational Psychology, vol. 12, núm. 2, mayo-agosto, 2014, pp. 325-342

Universidad de Almería

Almeria, España

Disponible en: http://www.redalyc.org/articulo.oa?id=293131824004

- Cómo citar el artículo

- Número completo

- Más información del artículo

- Página de la revista en redalyc.org

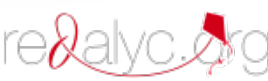

Sistema de Información Científica

Red de Revistas Científicas de América Latina, el Caribe, España y Portugal Proyecto académico sin fines de lucro, desarrollado bajo la iniciativa de acceso abierto 

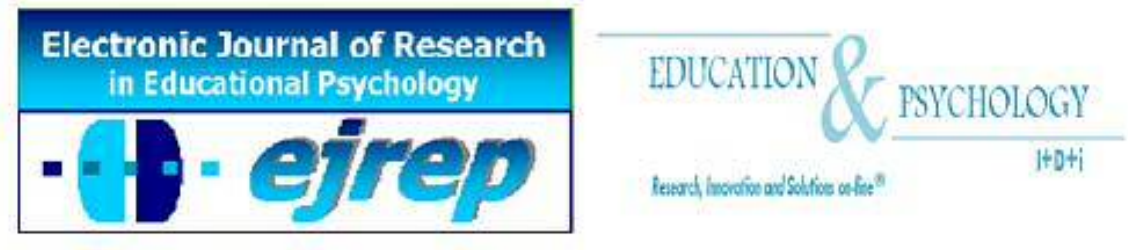

Ilustre Colegio Oficial de Psicología

DE ANDALUCIA ORIENTAL

\title{
Emotional Intelligence in Secondary Education Students in Multicultural Contexts
}

\author{
Pegalajar-Palomino; $M^{a}$ del Carmen'; \\ \& \\ Colmenero-Ruiz, Ma J esús ${ }^{2}$
${ }^{1}$ Facultad de Ciencias Sociales y de la Comunicación, Universidad Católica de Murcia. Murcia.
${ }^{2}$ Departamento de Pedagogía. Universidad de J aén. J aén.

Spain

Correspondence: $M^{a}$ del Carmen Pegalajar Palomino. Campus "Los Jerónimos", s/n. Murcia (Spain). E-mail: mdcpegalajar@ucam.edu

(c) Education \& Psychology I+D+i and Ilustre Colegio Oficial de Psicólogos de Andalucía Oriental (Spain) 


\begin{abstract}
Introduction. This study analyzes the level of development in emotional intelligence of Secondary Education students. It also checks for statistically significant differences in educational level between Spanish and immigrant students, under the integration program "Intercultural Open Classrooms".
\end{abstract}

Method. 94 students of Secondary Education in the province of J aen (Spain) have been involved; data was collected through a self-report questionnaire on emotional education (Emotional Quotient Inventory: Young Version, EQ-iL: YV).

Results. Outcomes show very high scores for each scale; "Stress management" and "Interpersonal" scales yielded the lowest scores. Similarly, there are statistically significant differences in the assessments of Secondary Education students according to their origin; Spanish students show the greatest skill in understanding and controlling their own emotions and communicating them to others. The analysis of variance reveals statistically significant differences between students by educational level; younger students show more positive assessments related to "Intrapersonal" and "Stress management" scales.

Discussion and conclusion. It is vital to implement programs that develop emotional intelligence with teenagers in multicultural contexts. Thus, through the development of these skills, a more humane and just society can be achieved, establishing conflict-free coexistence.

Keywords: emotional intelligence, students, immigration, Secondary Education. 


\title{
Inteligencia emocional en alumnado de Educación Secundaria en contextos multiculturales
}

\begin{abstract}
Resumen
Introducción. Esta investigación pretende analizar el nivel de desarrollo de la inteligencia emocional para alumnado de Educación Secundaria Obligatoria, comprobando la existencia o no de diferencias estadísticamente significativas en función del nivel educativo así como entre alumnado español e inmigrante que asiste al programa de integración Aulas Interculturales Abiertas.

Método. En el trabajo han participado 94 alumnos de un instituto de Educación Secundaria de la provincia de Jaén (España), utilizándose para la recogida de datos un cuestionario de autoinforme sobre educación emocional (Emotional Quotient Inventory: Young Version, EQ-i, Y).
\end{abstract}

Resultados. Los resultados revelan valores muy al tos para cada uno de los factores de la escala, siendo las dimensiones relacionadas con el manejo del estrés y la interpersonal en la que los estudiantes han manifestado menores puntuaciones. De igual modo, se destaca la existencia de diferencias estadísticamente significativas en las valoraciones del alumnado de Educación Secundaria Obligatoria según la procedencia de éste, siendo el alumnado español quién muestra mayores habilidades para entender sus propias emociones y comunicarlas a los otros así como para ejercer un control de las mismas. Finalmente, el análisis de varianza realizado revela la existencia de diferencias estadísticamente significativas entre el alumnado según su nivel educativo; así pues, son los alumnos más jóvenes quiénes muestran unas valoraciones más positivas relacionadas con la dimensión intrapersonal y de manejo del estrés y las emociones.

Discusión y conclusiones. Resulta de vital importancia implementar programas de inteligencia emocional con adolescentes desarrollados en contextos multiculturales. De este modo, y a partir del desarrollo de estas competencias, es como se podrá lograr una sociedad más humana y justa en la que se establezca una auténtica convivencia con ausencia de conflictos.

Palabras Clave: inteligencia emocional, alumnado, inmigración, educación secundaria.

Recibido: 05/12/13 Aceptación inicial: 15/04/14 Aceptación final: 29/06/14 
Introduction

The emotional intelligence topic has flourished in recent times; it is a construct which has an ample capacity to explain personal welfare and social success in organizations, families and educational institutions. Bar-On (2006) defines emotional intelligence as an interrelated set of skills, abilities and emotional and social facilitators that determine how effectively we understand and express ourselves, how we understand others and relate to them and how we face the demands of everyday life. He proposes fifteen subscales to define emotional intelligence; of these, ten are considered basic skills and refer to essential aspects of emotional intelligence (self-awareness, self-regard, assertiveness, empathy, interpersonal relationships, stress tolerance, impulse control, reality testing, flexibility and problem solving) and five scales are considered to be abilities that facilitate emotional intelligence (optimism, selfactualization, happiness, emotional independence and social responsibility). These fifteen subscales are organized into the following five major dimensions for the study of social and emotional characteristics of persons:

1) Intrapersonal: ability to understand one's own emotions and to communicate them to others.

2) Interpersonal: ability to understand and appreciate emotions in others.

3) Stress management: ability to direct and control one's own emotions.

4) Adaptability: flexibility and efficiency to resolve conflicts.

5) General mood: ability to have a positive attitude towards life.

Nowadays, education must address the development of socio-emotional skills in students, ranging from the protection of feelings, emotions and self-esteem to expansion of one's opportunities to choose, recognition of one's uniqueness, collective identity, individual personality and cultural particularity (Fernández \& Terrén, 2008). Formal education, especially those periods of Compulsory Education, represents a particularly suitable time for the development of basic skills for living together and establishing interpersonal relationships (Sanhueza \& Cardona, 2009). Incorporating these skills in education means a continuous, gradual learning process (Dueñas, 2002); it must be based on a diagnosis in order to give priority to the students' weaknesses, without neglecting the overall development of all such skills (Soriano \& Osorio, 2008). 
In particular, Secondary Education is a critical period for individual and social development, when young people face different situations that demonstrate their level of development in emotional intelligence. They leave behind elementary socialization, to interact with their peers in the quest for understanding and social acceptance (Zavala, Valadez \& Vargas, 2008). This is one of the most important challenges for teenagers, to establish and maintain good relations with people around them (Extremera \& Fernández-Berrocal, 2013).

Modern society is characterized by the creation of multicultural environments where each and every member of the educational community is required to understand and respect the diversity of languages, lifestyles, behaviors, feelings, emotions, etc. According to Repetto, Pena, Mudarra \& Uribarri (2007), contact with disparate ethnic groups requires recognition of a multiplicity of approaches and, therefore, the development of dialogical and democratic educational institutions, encouraging coexistence and empowerment of individual students and cultural approaches. The "Intercultural Open Classrooms" program, developed by the Spanish League for Education and Popular Culture and funded by the European Social Fund, aims to achieve socio-educational integration of immigrant students and their families in Primary and Secondary Education. Their goal is to form heterogeneous group spaces that facilitate intercultural experiences and learning exchange, through curricular adaptation and leisure time based on inter-culturalism, values education and coexistence.

Fajardo, Patiño and Patino (2008) define immigrant teenagers as a group at psychopathological risk in association with two processes: on one hand, the break with their place of origin and acceptance of the new culture and, on the other, the experience of youth, separation from old emotional attachments and the task of identity integration development at this stage of the life cycle. In addition, membership in a socially disadvantaged and/or poverty-stricken group, understood as the convergence of an economic deficit and a situation of social exclusion (Segura, 2010), can have a negative impact on the development and expression of social skills (Ayala, Pedroza, Morales, Chaparro \& Barragan, 2002). In this sense, Gualda (2008) refers to the importance of friendship networks for immigrant students, allowing them to leave the family enclosure, creating new viable alternatives beyond their family networks.

Emotional intelligence is defined as an extremely promising topic, although there is little research on the subject related to teenagers because, among other reasons, the instruments available for such study are adaptations of adult instruments or they are very recent. 
However, some research establishes positive relationships between emotional intelligence and academic achievement, prevention of risk behaviors, social adjustment and the quality and quantity of interpersonal relationships (Fernández-Berrocal, Extremera \& Palomera, 2008). Furthermore, emotional intelligence has been linked to students' subjective wellbeing (BarOn, 2005), social competence (Brasseur \& Gregoire, 2011; Zavala, Valadez \& Vargas, 2008) and social-school adjustment (Pena \& Repetto, 2008).

Díaz-Aguado and Baraja (1993), Leon, Felipe, Gomez, Gozalo and Lagas (2007), Rodriguez, Romero, Luque and Rocío (2002) and Siguan (1998) have shown that immigrant students have problems with social adjustment, social skills and, therefore, with social inclusion. Similarly, Fernandez, Gaete and Terrén (2008) confirmed lower levels of integration in the classroom among foreign students, compared to the Spanish group, with higher rejection rates and lower levels of acceptance among their classmates. Finally, Giró (2011), citing the report "Youth in Spain" (2004), points out how foreign teenagers seem to have more limited friendships; they need to feel sheltered by people of the same age and culture, because they are easier to identify with. They do not feel as close to Spanish teenagers, who are considered circumstantial friends.

It is interesting to analyze the influence of age and educational level on the emotional intelligence assessments of students. It is possible to establish educationalmechanisms to compensate for students' deficits at certain ages or education stages. However, Chan (2003) found that neither age nor gender influenced the scales of self-perceived emotional intelligence in students; Cuéllar (2012) argues that there are no age-or gender-associated differences that determine the relationship between interpersonal and intrapersonal intelligence and academic achievement in students. Meanwhile, Atkins and Stough (2005) showed that middle-aged adults are more likely than youth to be able to represent more complex emotions and to regulate and integrate them with their cognitions about the world. As children grow, the use of cognitive behavioral strategies increases, coming to resemble survival strategies of the adult (Saarni, 2000). However, Alvarez, Bisquerra, Fita, Martinez and Perez (2000) show how that as children age, their self-esteem level tends to decrease; beginning at the age of 14 is when development of emotional education programs becomes necessary. 
Objectives

Keeping such studies in mind, this paper aims to analyze the developmental level of emotional intelligence for Secondary Education students. In addition, it aims to check for statistically significant differences according to their educational level and between Spanish and immigrant students, under the "Intercultural Open Classrooms" program. To achieve this general aim, we have proposed the following specific objectives:

1) To analyze the developmental level of emotional intelligence in Secondary Education students.

2) To analyze the developmental level of emotional intelligence among Spanish and immigrant students under the "Intercultural Open Classrooms" program.

3) To compare emotional intelligence scores according to education level of Secondary Education students.

Method

Participants

The research was conducted during the 2012/13 academic year in a secondary school in the province of J aen (Spain). With a high number of non-EU immigrant students, it participates in the "Intercultural Open Classrooms" program for the integration of immigrant students.

The study population consists of 110 students from Secondary Education (from 1st to 4th year). The results were obtained using a non-probability sampling, accidental or casual type ( $n=94)$. Table 1 shows the sample distribution according to socio-demographic characteristics: 
Table 1. Sociodemographic data

\begin{tabular}{llll}
\hline \multirow{2}{*}{ Gender } & & $N$ & $\%$ \\
\hline \multirow{3}{*}{ Age } & Male & 47 & 50.0 \\
\cline { 2 - 4 } & Female & 47 & 50.0 \\
\cline { 2 - 4 } & Less than 13 years & 10 & 11.0 \\
\cline { 2 - 4 } & Between 14 and 16 & 62 & 68.1 \\
\cline { 2 - 4 } Course & Over 17 years & 91 & 20.9 \\
\cline { 2 - 4 } & 2) year Secondary Education & 25 & 26.5 \\
\cline { 2 - 4 } & 3rd year Secondary Education & 21 & 22.3 \\
\cline { 2 - 4 } & 4th year Secondary Education & 23 & 26.5 \\
\hline Snmigrant students & 25 & 39.8 \\
\hline
\end{tabular}

Instrument

The self-report questionnaire on emotional intelligence "Emotional Quotient Inventory, Youth Version" (Bar-On \& Parker, 2000), was used to collect data. Its main advantage is the application time and the item comprehensibility for students. This inventory contains information on the social and emotional competencies, thereby developing a social and emotional profile (Bar-On \& Parker, 2000). These authors have reported adequate reliability of the scales assessed in the questionnaire, with values ranging from .84 (intrapersonal) and .89 (total), while Ferrandiz, Ferrando, Bermejo and Prieto (2006) confirm a reliability of .87 for the total scale, and Prieto, Bai, Ferrandiz and Serna (2007) show adequate reliability (.89).

The questionnaire targets students between the ages of 6 and 18; it consists of 60 statements on a four-point Likert scale ( $1=$ it never happens to me, $4=$ it always happens to me), measuring the following aspects:

1) Intrapersonal: ability to understand their own emotions and communicate them to others;

2) Interpersonal: ability to understand and appreciate the emotions of others;

3) Stress management: ability to direct and control their own emotions;

4) Adaptability: flexibility and efficiency to resolve conflicts;

5) General mood: ability to have a positive attitude towards life. 


\section{Procedure}

The school administrators were contacted in order to explain the research aims and gain access to the students for questionnaire application. In addition, family consent was obtained, ensuring at all times data anonymity and confidentiality. The questionnaire was administered individually to each student during the morning hours, allowing enough time and adequate instructions for proper completion.

\section{Statistical analysis}

The Statistical Package for Social Sciences software (SPSS, version 21 for Windows) was used for data processing. A descriptive analysis of the emotional intelligence scales included in the questionnaire EQ-i: YV (average and standard deviations) was also carried out. Student's t test for independent samples was applied in order to discover any statistically significant differences in emotional intelligence development between Spanish and immigrant students who participate in the "Intercultural Open Classrooms" program. Any statistically significant differences in emotional intelligence development according to educational level were determined by performing a comparison of means using analysis of variance (ANOVA); a post hoc analysis using the Tukey test was also conducted to check for differences between all pairs of means in the context of the total sample, using a 95\% confidence interval.

Results

Secondary Education students get very high values for each scale of EQ-i: YV questionnaire (Table 2).

For General mood scale, the scores reveal how students feel happy and they accept themselves physically; they like to have fun and everything they do meets with their own satisfaction ( $A=3.04, S D=.291)$. The Adaptability scale also gave positive ratings for the students; they are able to find solutions and easily resolve difficult situations ( $A=2.90, S D=.392$ ). Likewise, students understand their own emotions and communicate them to others (Intrapersona/ scale) $(\mathrm{A}=2.80, \mathrm{SD}=.478)$. 
The scales in which students have obtained lower scores are related to Stress management $(A=2.73, S D=.415)$ and the Interpersonal dimension $(A=2.72, S D=.346)$. In certain situations, students have trouble keeping calm in circumstances that alter their life. On occasions, they are also involved in interpersonal conflict with friends and are unable to understand their emotions and feelings.

Table 2. Descriptive statistics of the EQ-i: YV scale

\begin{tabular}{lcccc}
\hline Scale & A & SD & Minimum & Maximum \\
\hline Intrapersonal & 2.80 & $(.478)$ & 1.83 & 3.67 \\
\hline Interpersonal & 2.72 & $(.346)$ & 1.83 & 3.58 \\
\hline Stress Mangement & 2.73 & $(.415)$ & 1.75 & 3.50 \\
\hline Adaptability & 2.90 & $(.392)$ & 1.80 & 3.70 \\
\hline General mood & 3.04 & $(.291)$ & 2.29 & 3.71 \\
\hline
\end{tabular}

The Student t test for independent samples was used to find statistically significant differences in emotional intelligence development between Spanish and immigrant students in the "Intercultural Open Classrooms" program (Table 3).

Results reveal statistically significant differences in Secondary Education students in the Intrapersonal $(t(72)=-2.03, p<.04)$ and Stress Management dimensions $(t(70)=-2.18$, p<.03). However, no statistically significant differences in Secondary Education students were observed for Interpersonal $(t(78)=1.95, p<.05)$, Adaptability $(t(69)=-.88, p=.38)$ and General mood scale $(t(70)=.71, p=.48)$.

Where they scored differently, Spanish student show greater ability to understand their own emotions and communicate them to others, as well as to exercise control over them. Immigrant students that participate in the "Intercultural Open Classrooms" program obtained lower scores on Intrapersonal and Stress management scales.

Table 3. Student's t test for the EQ-i: YV scale between immigrant and Spanish students

\begin{tabular}{lcccc}
\hline & $\begin{array}{c}\text { Inmigrant student } \\
\mathrm{A}(\mathrm{SD})\end{array}$ & $\begin{array}{c}\text { Spanish students } \\
\mathrm{A}(\mathrm{SD})\end{array}$ & $\mathrm{t}$ & $\mathrm{p}$ \\
\hline Intrapersonal & $2.66(.502)$ & $2.90(.447)$ & -2.06 & $.04^{*}$ \\
\hline Interpersonal & $2.81(.392)$ & $2.65(.303)$ & 1.95 & .05 \\
\hline Stress Mangement & $2.60(.444)$ & $2.81(.370)$ & -2.18 & $.03^{\star}$ \\
\hline Adaptability & $2.85(.431)$ & $2.94(.358)$ & -.88 & .38 \\
\hline General Mood & $3.07(.286)$ & $3.02(.297)$ & .71 & .48 \\
\hline${ }^{\star} \mathrm{p}<.05$ & & & &
\end{tabular}


Analyzing emotional intelligence development in students, it is interesting to establish in which student groups there are differences. Therefore, and to determine whether there are statistically significant differences between students according educational level, an analysis of variance (ANOVA) was performed.

This analysis has shown statistically significant differences for Intrapersonal $(F(4,70)=4.05, p=.00)$ and Stress Management scales $(F(4,68)=3.88, p=.00)$. However, no significant differences between student groups were observed for the Interpersonal $(F(4,76)=.47, p=.75)$, Adaptability $(F(4,67)=.97, p=.42)$ or General mood scales $(F(4,67)=.45, p=.77)$ (table 4).

In addition, the Tukey test reveals how for the Intrapersonal scales, first and second year students show significant differences when compared to students in their final year of compulsory Secondary Education (ESO) $(p<.0)$; novice students have the most favorable level of emotional intelligence development. Meanwhile, for the Stress management scale, the Tukey test shows how differences between students from second and third year of Secondary Education $(p<.01)$; in this case, as in the previous scale, younger students show more positive ratings of emotional intelligence.

Table 4. ANOVA for the EQ-i: YV scale according to educational level of students.

\begin{tabular}{lllllll}
\hline & 1st ESO & 2nd ESO & 3rd ESO & 4th ESO & \multirow{2}{*}{ ANOVA } & Tukey \\
& A(SD) & A(SD) & A(SD) & A(SD) & & \\
\hline Intrapersonal & $3.01(.355)$ & $2.88(.437)$ & $2.58(.525)$ & $2.38(.565)$ & $.00^{\star}$ & $1^{0}-4^{0} ; 2^{0}-4^{0}$ \\
\hline Interpersonal & $2.82(.339)$ & $2.69(.342)$ & $2.69(.325)$ & $2.79(.350)$ & .75 & \\
\hline Stress Mangement & $2.84(.439)$ & $2.84(.422)$ & $2.45(.312)$ & $2.45(.354)$ & $.00^{*}$ & $2^{0}-3^{0}$ \\
\hline Adaptability & $2.83(.497)$ & $2.99(.421)$ & $2.76(.325)$ & $2.80(.447)$ & .42 & \\
\hline General mood & $3.15(.386)$ & $3.03(.303)$ & $3.00(.282)$ & $3.02(.271)$ & .77 & \\
\hline${ }^{*} p<.05$ & & & & & &
\end{tabular}

Discussion and conclusions

This research analyzes the emotional intelligence of Secondary Education students in multicultural contexts. Furthermore, it has demonstrated statistically significant differences in their emotional intelligence development according to their educational level (year in school). 
This study undoubtedly offers an assessment of the socio-emotional skills in Secondary Education students (Spanish and immigrant), that can establish what areas should be addressed in classroom teaching (Soriano \& Osorio, 2008).

It is positive that Secondary Education students have quite acceptable scores on their assessments of emotional intelligence. These skills facilitate the emotional aspect of students' acquisition of knowledge, focusing on motivation and development of a suitable climate for learning in the context of the classroom and the school, which are essential for the managingconflict and school coexistence (Fernández-Berrocal \& Extremera, 2002).

Students showed a positive attitude towards life and what happens around them; they adopt criteria based on flexibility and effectiveness to resolve conflicts of daily life and they have qualities to understand their own emotions and communicate them to others. However, students had lower scores in managing their emotions and feelings and understanding their peers and people around them in certain circumstances. These data support the idea of developing emotional education programs for Secondary Education, to promote respect and acceptance of the "other" and their differences, and to prevent and correct any confrontations and conflicts routinely produced in schools and in society in general.

Regarding Spanish and immigrant students' scores on emotional intelligence, "native" students displayed greater emotional skills; they claim to understand and properly manage their own emotions and feelings. These results may be due to the drastic change and the tension that immigrant students experience as a result of moving from one country to another, changing the language, customs, culture, etc. In this regard, for teenagers who migrate, Feixa (2008) discusses how they cannot forget the past; they arrive at the destination with personal and social identities, conditioned by their primary socialization in their place of origin, more or less idealized images of the destination and the traumatic experience of the migratory adventure.

The results must cause us to question the educational action that takes place in the "Intercultural Open Classrooms" program, which seeks to help develop students' socioemotional skills and to thereby facilitate their personal welfare and their insertion in the environment. Similarly, research by DíazAguado and Baraja (1993), Leon et al. (2007), Rodriguez et al. (2002) and Siguan (1998) show how immigrant students have problems with social 
adjustment, social skills and, therefore, social inclusion. Likewise, Fernandez, Gaete and Terrén (2008) noted significantly lower integration in the classroom among foreign students as compared to the Spanish group, with higher rejection rates and lower levels of acceptance among their classmates.

As for educational level, lower-level students (first and second year in Secondary Education) show greater ability to understand their own emotions and communicate them to others than do upper-level students (fourth year of Secondary Education). Similarly, second-year students indicate greater ability to manage their own feelings than third year students. These differences may be due to the significant changes that are involved in the physical, cognitive, moral, social, psychosexual and emotional development of these youths; these changes influence the way they are and how they relate to the environment, even leading a sense of personal consistency and social discontinuity that may contribute to development of an identity crisis in adolescence.

These results concur with data provided by Alvarez et al. (2000), who showed that as students become older, it necessary to develop emotional literacy programs. However, authors like Chan (2003) and Cuellar (2012) showedno significant differences in student ratings of emotional intelligence according to age. Atkins and Stough (2005) established how middleaged adults have a greater ability to represent more complex emotions and regulate and integrate them with their cognitions about the world than do younger adults.

Ultimately, focusing on the development of teaching and learning quality, it is vital to implement emotional intelligence programs with teenagers in multicultural contexts. These programs should contain the emotional skills needed to perceive, understand and regulate emotions (Grewal \& Salovey, 2005). Through the development of these skills, a more humane and just society can be achieved, free of conflict.

However, the small size of the research sample does not guarantee the generalization of the results to other samples. Similarly, the exclusive use of self-reports as the instrument of data collection may present problems such as social desirability and sincerity. Also, one must consider how these scores on emotional intelligence in immigrant students have been obtained with Spanish scales. 
However, despite those limitations, there is no doubt that the study raises a number of questions that encourage continued research along this line. Thus, it may be interesting to plan the development of an emotional intelligence program for these students, comparing their ratings on emotional intelligence with those expressed in this study. Furthermore, the study sample could be extended, analyzing the emotional intelligence level of students raised in multicultural contexts in Primary Education and the ratings of other agents - such as families or teachers - regarding students' level of emotional intelligence could be taken into account. 
References

Álvarez, M., Bisquerra, R., Fita, E., Martínez, F. \& Pérez, N. (2000). Evaluación de programas de educación emocional. [Evaluation of emotional education programs.] Revista de Investigación Educativa, 18(2), 587-599.

Atkins, P. \& Stough, C. (2005). Does emotional intelligence change with age? Communication presented at the Society for Research in Adult Development Annual Conference. Atlanta: GA.

Ayala, H., Pedroza, F., Morales, S., Chaparro, A. \& Barragán, N. (2002). Factores de riesgo, factores protectores y generalización del comportamiento agresivo en una muestra de niños en edad escolar. [Risk factors, protective factors and generalization of aggressive behavior in a sample of school children] Salud Mental, 25(3), 27-40.

Bar-On, R. (2005). The impact of emotional intelligence and subjective well-being. Perspectives in Education, 23, 41-61.

Bar-On, R. (2006). The Bar-On model of emotional-social intelligence (ESI). Psicothema, 18, $13-25$.

Bar-On, R. \& Parker, J.D.A. (2000). Emotional Quotient Inventory: Youth Version (EQ-i: YV). Technical manual. Canada: Multi-Health Systems.

Brasseur, S. \& Gregoire, J. (2011). L’intelligence émotionnelle - Triz chez les adolescents á haut potential: Spécificités et liens avec la réussite scolaire et les competences socials. [Emotional Intelligence - TRIZ in adolescents with high potential: Specificities and links to academic success and socials skills] Enfance, 62(1), 59-76.

Chan, D.W. (2003). Dimensions of emotional intelligence and their relationships with social coping among gifted adolescents in Hong Kong. Journal of Youth and Adolescence, 32(6), 409-418. doi: 10.1023 / A: 1025982217398

Cuéllar, R. (2012). Relación entre inteligencia emocional y rendimiento académico en alumnos de Educación Primaria. [Relationship between emotional intelligence and academic performance in primary school students] Master's Final Paper. Universidad Internacional de La Rioja.

Díaz-Aguado, M.J. \& Baraja, A. (1993). Interacción educativa y desventaja sociocultural. [Sociocultural interaction and educational disadvantage] Madrid: CIDE.

Dueñas, M.L. (2002). Importancia de la inteligencia emocional: un nuevo reto para la orientación educativa. [Importance of emotional intelligence: a new challenge for the educa- 
tional approach] Educación XXI, 5, 77-96. doi: http://dx.doi.org/10.5944/educxx1.5.1.384

Extremera, N. \& Fernández-Berrocal, P. (2013). Inteligencia emocional en adolescentes. [Emotional intelligence in adolescents] Padres y Maestros, 352, 34-39. doi: http://dx.doi.org/10.14422/pym.v0i352.1170

Fajardo, M., Patiño, M.I. \& Patino, C. (2008). Estudios actuales sobre aculturación y Salud Mental en inmigrantes: Revisión y perspectivas. [Current studies on acculturation and immigrant Mental Health: Review and perspectives] Revista Iberoamericana de Psicologiía: Ciencia y Tecnología, 1, 39-50.

Feixa, C. (2008). Generación Uno Punto Cinco. [Generation One Point Five] Revista de Estudios de Juventud. 80, 115-127.

Ferández-Berrocal, P. \& Extremera, N. (2002). La inteligencia emocional como una habilidad esencial en la escuela. [Emotional intelligence as an essential skill in school] Revista Iberoamericana de Educación, 29, 1-6.

Fernández, M. \& Terrén, E. (2008). De inmigrantes a minorías: temas y problemas de la multiculturalidad. [Immigrant minorities: issues and problems of multiculturalism] Revista de Educación, 345, 15-21.

Fernández, M., Gaete, J.M. \& Terrén, E. (2008). ¿Fronteras en las aulas? Contacto transcultural y endogamia en las interacciones del alumnado. [Are there Borders in Classrooms? Cross-cultural Exchange and Endogamy in Students' Interactions] Revista de Educación, 345, 157-181.

Fernández-Berrocal, P., Extremera, N. \& Palomera, R. (2008). Emotional intelligence as a crucial mental ability on educational context. In A. Valle, J.C., Núñez, R.G., Cabanach, R.G., González-Pineda, J.A. \& Rodríguez, S. (Eds.). Handbook of Instructional Resources and Their Applications in the classroom (pp. 67-88). Madrid: Nova.

Ferrándiz, C., Ferrando, M., Bermejo, M.R. \& Prieto, M.D. (2006). Emotional intelligence and personality. Communication presented to the British Educational Research Association (BERA). Warwick University.

Giró, J. (2011). Las amistades y el ocio de los adolescentes, hijos de la inmigración. [Friendships and activity of adolescent children of immigrants] Papers, 96(1), 77-95.

Grewal, D. \& Salovey, P. (2005). Feeling smart: The science of emotional intelligence. American Scientist, 93, 330-339.

Gualda, E. (2008). Identidades, autoidentificaciones territoriales y redes sociales de adolescentes y jóvenes inmigrantes. [Identities, territorial self-identifications and social net- 
works of adolescents and young immigrants] Portularia, Revista de Trabajo Social, $8(1), 111-129$.

León, B., Felipe, E., Gómez, T., Gozalo, M. \& Lagas, C. (2007). Socialización y autoconcepto en una muestra de alumnos inmigrantes marroquíes. [Socialization and self-concept in a sample of Moroccan immigrant students] Apuntes de Psicología, 25(1), 53-65.

Pena, M. \& Repetto, E. (2008). Estado de la investigación en España sobre inteligencia emocional en el ámbito educativo. [The state of research in Spain on emotional intelligence in education] Revista Electrónica de Investigación Psicoeducativa, 15(6), 400420 .

Prieto, M.D., Bai, L., Ferrandiz, C. \& Serna, B. (2007). Psychometric Characteristics of EQi:YV in an English sample. Paper presented at the First International Congress on Emotional Intelligence. Málaga (Spain). September $19^{\text {th }}-21^{\text {th }}$.

Repetto, E., Pena, M., Mudarra, M.J \& \& Uribarri, M. (2007). Orientación de las competencias socioemocionales de los alumnos de Educación Secundaria en contextos multiculturales. [Orientation of socio-emotional skills of secondary students in multicultural contexts] Revista Electrónica de Investigación Psicoeducativa, 5(1), 159-178.

Rodríguez, G., Romero, J.F., Luque, D. \& Rocío, L. (2002). Integración escolar y rendimiento de una muestra de alumnos inmigrantes de Algeciras. [School integration and performance of a sample of immigrant students in Algeciras] Psicología Educativa, 8, 5-20.

Saarni, C. (2000). Emotional Competence. A Developmental Perspective. In R. Bar-On \& J.D.A. Parker (Eds.). The Handbook of Emotional Intelligence. Theory, Development, Assessment and Application at Home, School and in the Workplace (pp. 68-91). San Francisco, Ca: Jossey-Bass.

Sanhueza, S.V. \& Cardona, M.C. (2009). Evaluación de la sensibilidad intercultural en alumnado de Educación Primaria escolarizado en aulas culturalmente diversas. [Assessing the intercultural sensitivity of primary education students enrolled in culturally diverse classrooms] Revista de Investigación Educativa, 27(1), 247-262.

Segura, P. (2010). Pobreza y exclusión social. Diagnóstico de los distritos 4 y 5 de Melilla. [Poverty and social exclusion. Diagnosis of districts 4 and 5 of Melilla] Melilla: Ministerio de Trabajo e Inmigración.

Siguán, M. (1998). La escuela y los inmigrantes. [The school and immigrants] Barcelona: Paidós Ecuador. 
Soriano, E. \& Osorio, M.M. (2008). Competencias socioemocionales del alumnado "autóctono" e inmigrante en educación secundaria. [Socio-emotional skills of "native" and immigrant students in secondary education] Bordón, 60(1), 129-148.

Zavala, M.A., Valadez, M.D. \& Vargas, M.C. (2008). Inteligencia emocional y habilidades sociales en adolescentes con alta aceptación social. [Emotional intelligence and social skills in adolescents with high social acceptance] Revista Electrónica de Investigación Psicoeducativa, 6(2), 319-338. 